\title{
Analysis of Student Errors in Learning Circle Based on the Watson Error Category
}

\author{
Ni Nyoman Riantini, I Nengah Suparta, I Gusti Putu Sudiarta \\ Universitas Pendidikan Ganesha, Jalan Udayana nomor 11 Kec Buleleng, Kab Buleleng, 81116 Bali Indonesia \\ e-mail: gekrian@gmail.com
}

\begin{abstract}
Error analysis is a process of reviewing students' answers to identify patterns of understanding. Errors in mathematics are considered as deviations from the actual solution of a problem. The aim of the study is to analyze student errors based on the Watson error category learning circle. In this study students were given 5 essay mathematical problems, and then analyzed their errors based on 8 Watson error categories and continued by interviewing 1 student for each category of error. This study was conducted at SMP PGRI 3 Denpasar in a class on IX grade with 40 students. The results show that the percentage of student errors categories obtained from this study as follows: comprehension errors $54 \%$, transformation errors $18 \%$, process skills errors $15 \%$, encoding errors $7 \%$. Students are interviewed to find out carelessness and motivation that affect students' mistakes. While for question form category we found no errors.
\end{abstract}

Keywords: Error Analysis, Watson Error Category, Circle

How to Cite: Riantini, N.N., Suparta, I.N., \& Sudiarta, I.G.P. (2020). Analysis of Student Errors in Circle Subject Based on the Watson Error Category. International Journal on Emerging Mathematics Education, 4(1), 31-42. http://dx.doi.org/10.12928/ijeme.v4i1.15840

\section{INTRODUCTION}

In mathematics, error is interpreted as a deviation from the actual solution of a problem. Some student mistakes are not just carelessness, lack of confidence in answering or other unique things that are unexpected but are a result of the learning process as long as students take math lessons (Legutko, 2008). Errors made by high school students were analyzed for patterns and their causes. The origins of errors were intuitive assumptions, failure to understand the syntax of algebra, analogies with other familiar symbol systems such as the English alphabet and interference from arithmetic (Egodawatte, 2009).

\section{Error Analysis}

Analysis of student errors may show difficulties that experienced by students, as a result of the failure of students to understand a concept thoroughly. It can also be seen how errors in problem solving and providing information about students' understanding and attitudes in dealing with mathematical problems. Error analysis focuses on students' weaknesses in understanding learning. Lai (2012) error analysis is a method commonly used to identify the cause of student errors when they make consistent mistakes.

Error analysis gains importance in two respects. First, with regard to the requirements of academic practice, as an opportunity to diagnose learning difficulties, as a method of developing criteria for differentiating mathematical education, and as a means to create more awareness and support for the performance and understanding of individual students. Second, error analysis seems to be a remarkable starting point for research on the mathematical teaching-learning process Error analysis must be 
considered a promising research strategy for clarifying some fundamental questions of mathematics learning (Radatz, 1980). Rohmah (2017) said error analysis is needed to find out how students solve mathematical problems.

As stated at the beginning, analysis of student errors can provide a good picture to know why students have difficulty in learning mathematics. By checking students' mistakes may show students' concept understanding. On the other hand, correct student answers may not necessarily indicate a good conceptual understanding of related knowledge because students can solve problems correctly just by remembering procedures or definitions without correct understanding. (LI, 2006)

Analysis of student errors can also be done based on the material or subject matter being studied, so teacher can find out the mistakes or weaknesses of students in working on different material or subject. In addition, in analyzing the errors, it can also be used error categories according to Watson categories. Watson who made an error analysis on the way students work with 8 categories of errors that were developed from the Newman error categories namely reading, comprehension, transformation, process skills, coding, motivation, carelessness and question form. This category can be elaborated through the Figure 1.

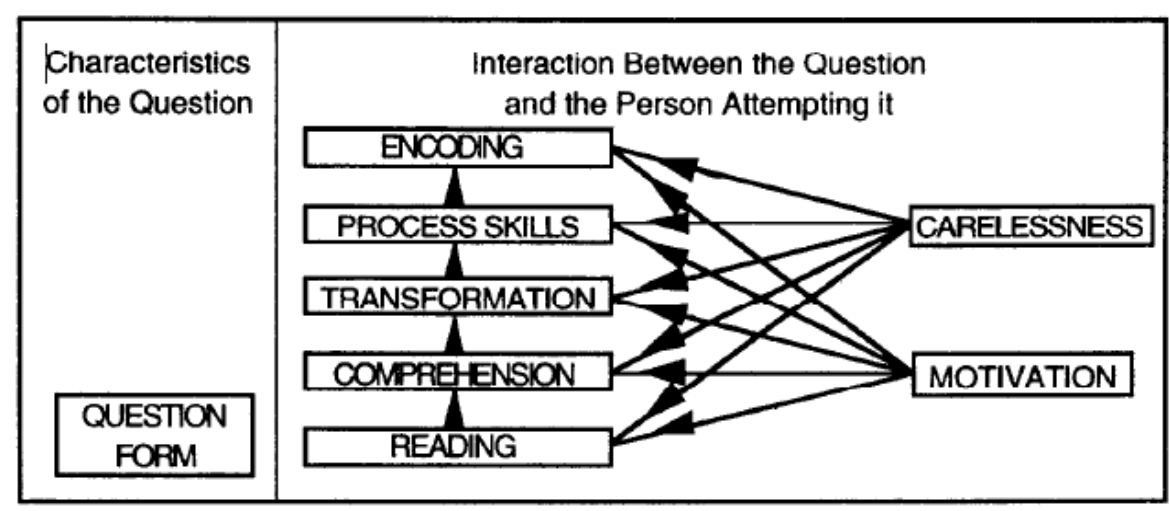

Figure 1. Interaction of Watson' Error Category

The form of questions is placed separately from other categories because the difficulties and errors that might arise are influenced by the problem or the question itself without any interaction with the student completing the problem. Two other categories of motivation and carelessness are also placed separately with five categories of "hierarchy" because these categories of errors can occur or affect 5 other categories (M.A ("Ken") \& Nerida, 1996). Fong (1993) said the psychological knowledge involves motivation and carelessness in problem solvers' written work

Research on error analysis in the Watson category has been carried out with a variety of different material. The results of (Chrisnawati, 2012) study, she analyze student errors in VIII grade based on the Watson category with the result that the most incorrect procedure errors occur. In addition, not all categories in the Watson category were found in this study. Susilawati \& Febrian (2016) regard error analysis in student in the first year of high school on probability subject based on the Watson category. The results of this study get the conclusion that the most mistakes occur at the conclusion of missing conclusions. An individual need to activate his/her information about the use of problem solving and reading comprehension skills and effect a transfer of information between these skills. For the evaluation of whether such a transfer takes

IJEME, Vol. 4, No. 1, March 2020, 31-42. 
place, these two skills must be observed together, while for the development of problem solving and reading comprehension skills, they need to be observed and evaluated in the long run (Gökhan, 2015).

Error analysis based on Watson category can detail students' mistakes in circle material more clearly and focus both on calculations and concepts that are less mastered. Example in the category of carelessness becomes a category that can explain how mistakes are actually made whether indeed from carelessness or lack of student understanding of the material provided. The results of research conducted (Wiens, 2007) states by clearly marking errors in the form of carelessness, after being returned to students the work is made to get a positive response from students and then students try not to make carelessness again so as not to get the wrong sign or usually in the form scribble.

Circle is one subject of geometry field that students learn since elementary school. In the GCSE paper explained errors that often occur in the circle material including confusion between the radius and diameter, lack of understanding of the use of the formula of area and circumference of a circle, as well as looking for the magnitude of the angle in the area of the circle (OECD, 2011; Hendroanto, et al. 2018). From the explanation and researcher' experience many students make mistakes in solving problems about circle material.

Based on the explanation above, writer is interested to study about "Analysis of Student Errors Based on the Watson Errors Category in Solving Mathematical Problems in the Circle Subjects". The aim of this research is to find out whether students' errors solve mathematical problems on the subject of a circle based on the Watson error category and the factors that cause students to solve mathematical problems on the circle material.

\section{RESEARCH METHOD}

This research approach is qualitative research. The results of qualitative research emphasize meaning rather than generalization (Sugiyono, 2008). This study aims to determine students' mistakes in solving mathematical problems on the subject of a circle based on the Watson category.

The subjects of the study were the IX grade students of SMP PGRI 3 Denpasar who were selected through a purposive technique. The determination of the research subject was taken in a class on IX grade which was considered by the mathematics teacher who was teaching. After being given a test, students who made mistakes based on the Watson category were selected for further interviews. The subject of the interview was chosen using a purposive technique where if the predetermined subject did not provide indepth information, the student would be re-selected for interview. The data obtained in this study are test result data and interview data. In this case the data analysis is done, namely reducing data, data exposure and making conclusions.

\section{RESULTS AND DISCUSSION}

This research was conducted at SMP PGRI 3 Denpasar by taking subjects in 1 class on IX grade. This class had already studied circle material so that they were able to answer the tests given. Students given 5 pieces of questions with the circle subject, after the answers obtained students made an analysis of the mistakes made by students in answering. These errors are categorized in the Watson error category. After being categorized based on the Watson error category to corroborate the results of the students' error analysis interviews were conducted of students who made mistakes 
based on each of Watson's wrong categories. Then taken 1 student in each category who made the mistake repeatedly or more than once.

\section{Comprehension Error}

Question:

A piece of pizza shaped round pie as shown below

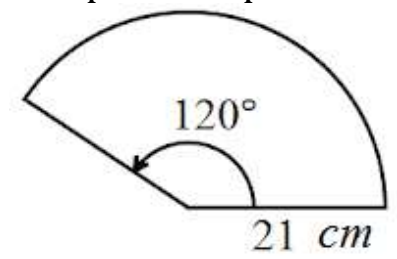

Determine the circumference of the pizza is ...

S2 answers:

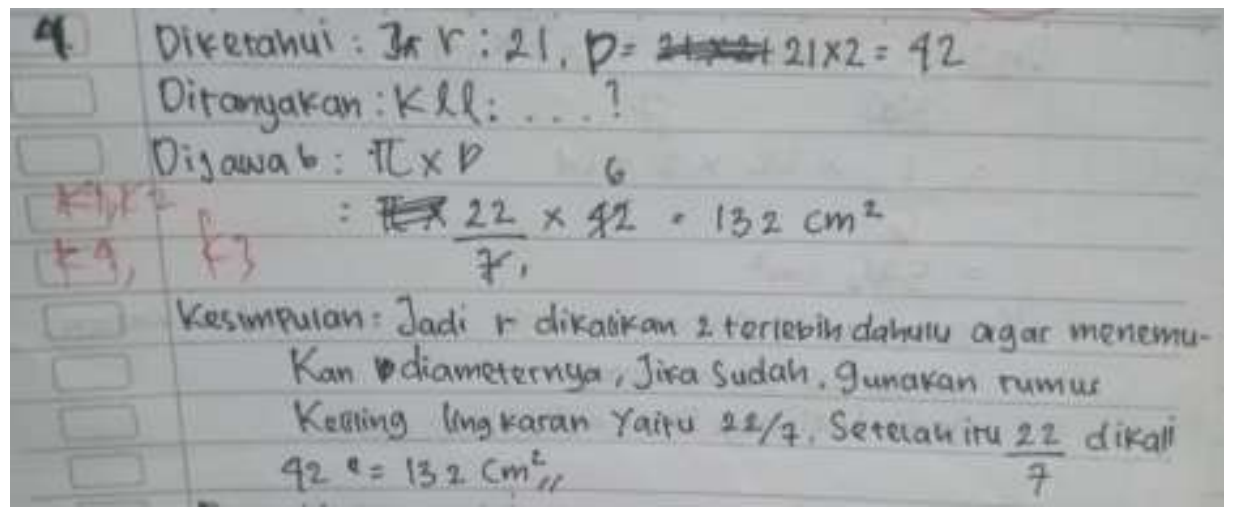

Figure 2. Comprehension Error by S1 for Question Number 4

Translation from Figure 2

Known: radius $=21$, diameter $=42$

Ask: circumference $=\ldots$ ?

Answer: $22 / 7$ x $42=132 \mathrm{~cm}^{2}$

Conclusion: So, radius multiple by 2 to get diameter, then use formula of circumference circle to find the answer $22 / 7 \times 42=132 \mathrm{~cm}^{2}$.

From Figure 2 we can say that S1 didn't understand what was asked. Students only write the circumference, where the student only means the circumference of a circle, even though the question is meant to ask about the circumference of a pizza in the shape of a circle with its center angle and radius $21 \mathrm{~cm}$. To clarify and strengthen the results of the researcher's analysis along with the results of interviews with $\mathrm{S} 1$.

Interviews were conducted with $\mathrm{S} 1$ as follows.

$\mathrm{P}$ : Student, you try to read again about this. (pointing to the problem)

S1: Read the problem clearly but doubt when pointing to the picture

$P$ : Now try to explain what info you get from the problem.

S1: There is a slice of pizza, there is this corner (pointing to the picture) and $r 21$ $\mathrm{cm}$ bu.

IJEME, Vol. 4, No. 1, March 2020, 31-42. 
Q: well so there is a central angle that is known, so what exactly is asked about that problem?

S1: Go circumference the pizza, bu.

$P$ : yeah right. Then why don't you write down what was asked in full here? Do you think looking circumference the circle is the same as looking circumference a slice of pizza with a central angle?

S1: Yes ma'am, because both looking circumference too. But I don't know about that angle.

Q: So do you think this problem is difficult?

S1: Yes ma'am because I don't know how.

Based on interviews with S1 errors in understanding questions occur because students are not able to associate what is known with what is the question in the problem. Students should find the length of the arc first with a known center angle, and add it by 2 times the length of the radius as the circumference of the pizza. Students can show what information is in the problem, but there is doubt when showing the central angle in the picture. It shows students are still confused about what to do to find the circumference if there is an angle in the middle. Then students continue to use the circumference of the circle to make it more clearly in accordance with what is known. Students lack of mastering the concept of a circle causes students not understand what is asked on this problem. It shown by students stating that the problem is difficult because they do not know what way to use.

\section{Transformation Error}

Question:

The area of the circle is $1386 \mathrm{~cm}^{2}$. The length of the circle's diameter is ... $\mathrm{cm}$

S2 answers:

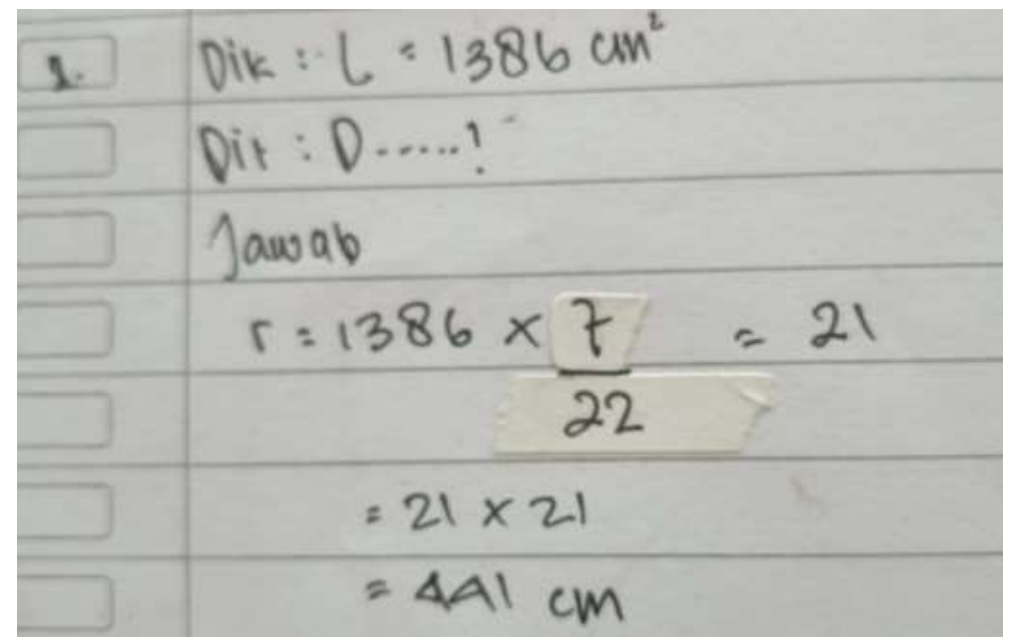

Figure 3. Transformation Error by $\mathrm{S} 2$ for Question Number 1

Translation from Figure 3

Known: Area $=1386 \mathrm{~cm}^{2}$

Ask: Diameter $=\ldots$ ?

Answer: radius $=1386 \times 7 / 22=21$

$$
\begin{aligned}
& =21 \times 21 \\
& =441 \mathrm{~cm}
\end{aligned}
$$


Figure 3 show use wrong formula to find diameter of circle. Students have given the right way to find the radius of the circle, but they are wrong in writing the solution to find the diameter of the circle.

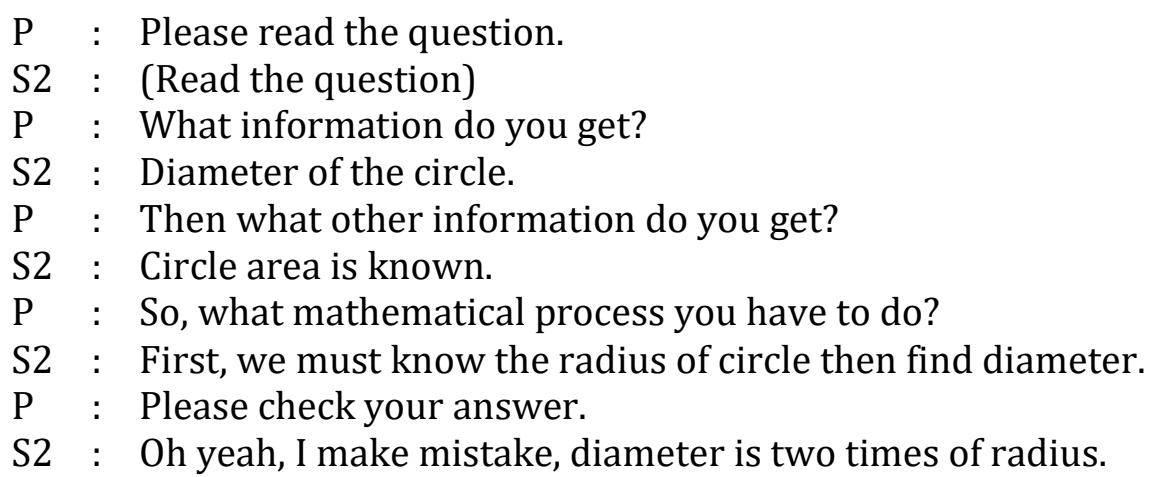

Based on the results of interviews of researchers and S2, it is known that students fail to provide solutions in accordance with the formula to find answers. Students did not write down the exact circle diameter formula that is asked on the questions, but at the interview stage students have been able to say correctly. This happens because students do not focus on the final solution, after understanding what is asked students can complete the initial stages to find the radius of the circle, after that students forget the formula to find the diameter of the circle. Students consider the problem quite easy because at the beginning there is no problem in writing the solution but the final answer writes the circle diameter formula incorrectly.

\section{Process Skill Error}

Question:

The area of the circle is $1386 \mathrm{~cm}^{2}$. The length of the circle's diameter is ... $\mathrm{cm}$

\section{S3 answers:}

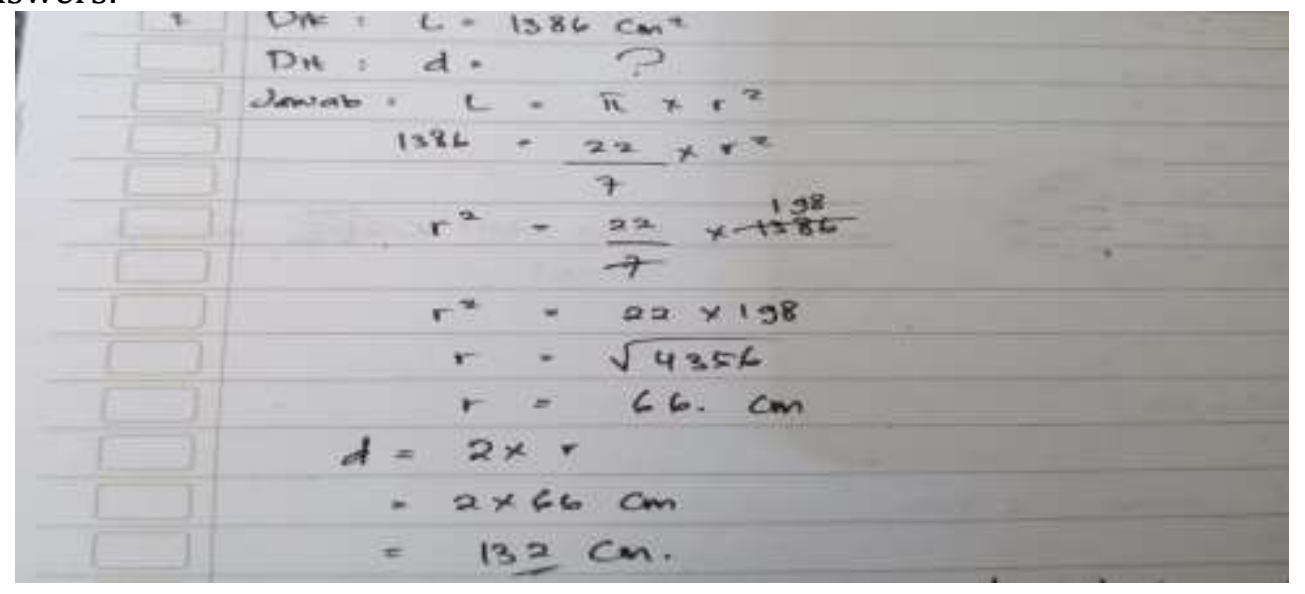

Figure 4. Process Skill Error by S3 for Question Number 1

Translation for Figure 4

Known: Area $=1386 \mathrm{~cm}^{2}$

Ask: diameter $=\ldots$ ?

Answer: Area $=\pi \times \mathrm{r}^{2}$

IJEME, Vol. 4, No. 1, March 2020, 31-42. 


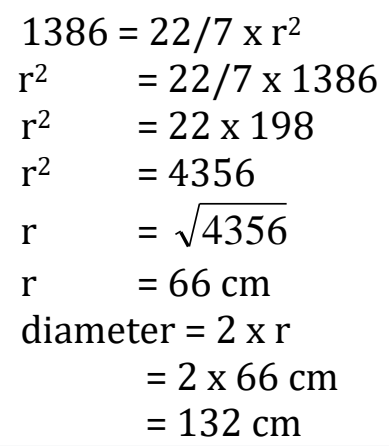

Student showed wrong calculation operations on the correct formula. The student has written the formula for the area of a circle correctly to get the length of the radius, but the student is doing the wrong calculation operation. To find the radius of the circle, the area of the circle should be divided by $\pi$, but students write it in multiplication form.

To get the results of a stronger analysis, interviews with S3 are as follows.

P : student try to read again about this. According to how the mathematical calculations to answer it.

S3 : So, this uses the broad circle formula Ma'am. Because of its known extent.

$\mathrm{P}$ : After using the circular area formula, what else is done?

S3 : find the fingers first, then you can find the diameter by multiplying $r$.

$\mathrm{P}$ : Please pay attention to the calculation in finding the radius - is this correct?

S3 : Hmmm (paying attention to the answers written) eh what should I do ma'am. Oh yeah, wrong, ma'am, how come it's so big.

$\mathrm{P}$ : So you already know the mistake? How should I count it?

S3 : This should be divided, mom, broadly equal to $22 / 7$, but I am wrong this time.

But I found the answer hehe.

According to the researchers' suspicion that the calculation error was because the students did not re-check the calculation process after getting round answers so it was felt that what was calculated was correct. Errors in these calculations often occur, especially in the process of dividing in the form of fractions. This is related to fraction operations and algebra operations that should have been mastered early on but are still often done carelessly. Students actually understand what is meant by the problem and have been transformed into mathematical form correctly, but this calculation error still makes the final answer incorrect.

\section{Encoding Error}

Question:

Look at the circle image centered on the following 0 .

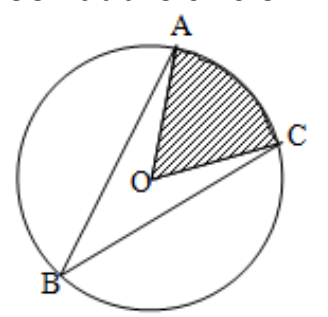

$\angle \mathrm{ABC}=60^{\circ}$ and $\mathrm{OA}$ length $=14 \mathrm{~cm}$. AOC's extensive area is... 
S4 answers:

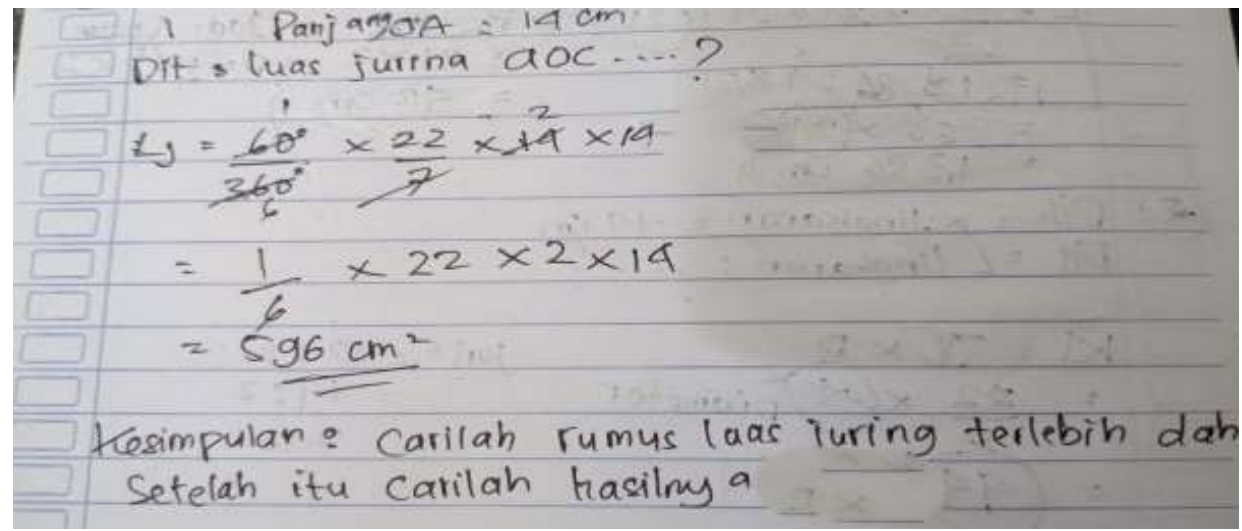

Figure 5. Encoding Error by S4 for Question Number 5

Translation for Figure 5

OA length $=14 \mathrm{~cm}$

Ask: Area of circle sector $=\ldots$ ?

Answer: Area $=60 / 360 \times 22 / 7 \times 14 \times 14$

$$
\begin{aligned}
& =1 / 6 \times 22 \times 2 \times 14 \\
& =596 \mathrm{~cm}^{2}
\end{aligned}
$$

Conclusion: find circle sector formula first, then find the answer.

From the answers, it can be seen that students experience errors in writing conclusions, not writing correctly and completely according to what is being asked in the questions.

To strengthen the analysis the researcher conducted an interview with S5 with the following results.

P : After working on this problem, try to conclude what you get after solving the problem?

S4: I can find the area of circle sector, ma'am. So the formula for wide area is sought.

$\mathrm{P}$ : So what is the conclusion to this problem?

S4: The conclusion is searched area of circle sector obtained $596 \mathrm{~cm}^{2}$.

$\mathrm{P}$ : Are you sure about the final answer that you made according to what was asked in the problem?

S4: Hmmm, I should, Ma'am, because it's already extensive touring according to the question. But I don't know, Ma, is the formula correct or not.

$\mathrm{P}$ : well in the final process I have found the area of circle sector with the right formula. So are there any difficulties in determining the final answer or in drawing conclusions?

S4: The conclusion is difficult, ma'am because of the length of what needs to be done, Ma'am.

P : Wow, you should just draw a conclusion like that. So that conclusion is the final answer to the process that you have worked on to show that what you have answered is in accordance with what was asked in the problem.

IJEME, Vol. 4, No. 1, March 2020, 31-42. 
S4: oh so I was wrong, ma'am. Hmm but I have written the way that is in accordance with what was asked. Uh, but the answer is not yet, ma'am.

$P$ : Yes, that is not right on your conclusion, you did not conclude or show your final answer so it cannot be determined according to or not the question.

S4: Yes ma'am, thank you for being explained. I was wrong in concluding all the problems yes ma'am.

The analysis showed that students did not know how to provide conclusions or final answers to a problem. Students assume by explaining what is done in the process of working on the problem as the final answer after completing a problem. Error in writing conclusions by S4 on the five questions explains that students write conclusions in accordance with what is thought about the conclusions. The mistake by S4 shows that students still do not understand how to provide the final answer of the work process. Students still interpret it as a conclusion of what method is used in solving problems. Because this understanding sometimes students even forget or deliberately do not make conclusions for reasons as described S4, conclusions are difficult because it is long to explain how to solve the problem.

\section{Carelessness}

Carelessness becomes a mistake that affects other categories of errors. Carelessness is part of student knowledge based on psychological factors. For this reason, it can be seen through direct interviews with students who make mistakes. Carelessness that is done on every problem is not repeated, this carelessness can be shown directly during interviews with students, so that it can explain how carelessness can occur and not because of lack of understanding of the concept. The initial carelessness of students is shown by the incomplete information written, this continues to influence the workmanship of the next process. The students seemed to be convinced of what was made, but the results obtained were not appropriate. Students also make carelessness in the process of working on other questions. So carelessness that is usually done by students on small things but can influence from the initial stages of answering to the time of concluding.

\section{Motivation}

Interviews were conducted to find out what made students not answer questions and to strengthen the analysis of researchers in the motivation category.

$\mathrm{P}$ : Son, why isn't this problem solved?

S6: Yes ma'am, sorry at that time I was called out of class. So there is no time to make ma'am.

P : I see, now you try to solve this problem.

S6: Alright ma'am, I tried it, because I already forgot, mom. (trying to do)

$\mathrm{P}$ : Yes for this problem you have understood enough and made the right transformation, but not the final answer yet. Do you have any difficulty working on these problems?

S6: Actually, at that time I hadn't learned, ma'am, so when I was asked to go out of the classroom to take part in activities for a while, I was less eager to answer this question when I returned to my class

$\mathrm{P}$ : Well, this shows your lack of motivation in working on problems. 
Based on the results of the interview it can be seen that the motivation of S6 is weak in working on problems. Students do not work on 4 questions because they feel they are not ready, and they have less time. Motivation can also be seen from how students do not complete the answers until they get the final answers.

Factors That Cause Student Mistakes in Solving Mathematical Problems in the Circle subject. First, an error in understanding the cause is that it is difficult for students to associate what keywords are in the problem with the existing questions. In addition, students are also still unable to read the symbols in the picture and associate with elements in the circle, especially regarding the central angle and the circumferential angle. The solution that can be done to minimize or avoid this mistake is to provide an understanding of the concept of a circle in depth. This can be done by training various types of questions about the material circle so that students can understand the concept in depth not only on the formula or understanding of the elements.

Second, the most frequent transformation errors occur where students are unable to form appropriate mathematical models. This is due to students not understanding the concept of the formula in the circle material so that it is difficult to manipulate the algebraic form in the formula to find answers that fit the question. The solution to minimizing transformation errors is to ensure that each formula given to students can be understood for use. Students must also give focus when the teacher explains the completion of the questions and what formulas to use, because when transformation is not enough just to memorize the formula but also apply it according to what known to the problem

Then, Process skill errors are caused by students not being proficient with calculations in the form of fractions and algebraic manipulation. There are also many who are not trained in arithmetic so that they are lazy in completing arithmetic operations with large numbers, even though they are simple arithmetic operations such as division and multiplication. The solution to minimize process skill mistakes begins with always checking the previous stages of what is known and asked correctly, followed by transforming it in the correct mathematical form. If the previous stages are correct, followed by the correct calculation, students must ensure that they are able and accustomed to calculating various arithmetic and algebraic operations because these are basic things in process skills

Furthermore, encoding error due to students not accustomed to writing back the final answer and associating with questions on the problem. Students are also always in a hurry to finish the problem without wanting to double check the process until the final answer is in accordance with what was asked. The solution to minimizing errors in writing this conclusion is to always give students time to recheck the entire process of work and then write the final answer in accordance with what was asked. Familiarizing students with re-checking their work can be done not only on the provision of daily assessments or final assessments, but every practice question such as quizzes or daily tests.

Next, Carelessness caused by lack of accuracy and lack of training in answering questions. Carelessness will affect other stages in answering, starting from reading the questions, understanding the questions, the work process to writing conclusions. Carelessness is also caused by students lacking confidence in answering questions so that they often skip the calculation steps that cause calculation errors, students who lack confidence also make them unfocused in reading or already feel afraid to answer questions. To be able to minimize carelessness can be done by getting students to re-

IJEME, Vol. 4, No. 1, March 2020, 31-42. 
check their answers from the initial stage to the conclusion, because carelessness can cause errors from various stages of answering.

Last, Motivation will be a category due to influence from outside and inside students. Motivation can be influenced by oneself who doesn't want to study more and feels uninterested in circle material. Influence from the outside because of seeing friends who can answer quickly so that student motivation becomes wrong motivation by just cheating on friends' answers and the work gets done quickly. This motivation also affects all of the steps, weak motivation makes mistakes from the reading stage to concluding. Motivation is the initial capital in solving problems, because with good motivation students will complete the work on the problem with the focus from the initial step to the conclusion. Forming this motivation can be done by the teacher from the beginning of the learning process to providing daily assessments.

\section{CONCLUSION}

Based on the formulation of the problem, the results of the analysis and discussion can be concluded students' mistakes based on Watson error categories are comprehension errors, transformation errors, process skill errors, encoding errors and motivation. From the interview we can know that carelessness and motivation affect the other categories.

Factors that cause students to mistake on the circle subject students lack focus in working on the problem, the lack of students' understanding of the elements of the circle and also the formula in the circle material, less often practice the application of the formulas on the circle subject, and students do not have a strong motivation to solve the problems given.

\section{REFERENCES}

Chrisnawati, U. N. (2012). Analisis Kesalahan Siswa Kelas VIIII SMP dalam Menyelesaikan Soal Pokok Bahasa Lingkaran dengan Panduan Kriteria Watson. Skripsi. Surakarta: Universitas Muhammadiyah Surakarta

Egodawatte, Gunawardena. (2009). Is algebra really difficult for all students?. Acta Didactica Napocensia, 2(4). 102-106

Fong, Ho-Kheong. 1993. Schematic Model for Categorizing Children's Errors In Mathematics. Third International Seminar on Misconceptions and Educational Strategies in Science and Mathematics, Ithaca, 1-28

Gökhan, Özsoy. (2015). Evaluation of Students' Mathematical Problem-Solving Skills in Relation to Their Reading Levels. International Electronic Journal of Elementary Education, 2015, 8(1), 113-132. ISSN:1307-9298

Hendroanto, A., Istiandaru, A., Syakrina, N., Setyawan, F., Prahmana, R. C. I., \& Hidayat, A. S. E. (2018). How Students Solves PISA Tasks: An Overview of Students' Mathematical Literacy. International Journal on Emerging Mathematics Education, 2(2), 129-138.

Lai, Cheng-Fei. (2012). Error Analysis in Mathematics. Behavioral Research and Teaching. Thesis. Eugene: University of Oregon.

Legutko, M. (2008). An analysis of students' mathematical errors in the teachingresearch process. Handbook for mathematics teaching: Teacher experiment. A tool for research, 141-152.

LI, X. (2006). Cognitive Analysis of Students' Errors And Misconceptions In Variables, Equations, And Functions. Texas: A\&M University. 
M.A. ("Ken"), C., \& Nerida, E. (1996). Newman Error Analysis Research, and Implications for the Issue of "What is Basic?" In Mathematics Education Research: Past, Present and Future. Thailand: UNESCO Principal Regional Office for Asia and the Pacific.

OECD Publishing. (2011). Education at a glance 2011: OECD indicators. Organisation for Economic Co-operation and Development.

Radatz, Hendrik. 1980. Students' Errors in the Mathematical Learning Process: a Survey. For the Learning of Mathematics, 1(1), 16-20

Rohmah, Mushlihah. (2017). Analysis Problem Solving in Mathematical Using Theory Newman. EURASIA Journal of Mathematics, Science and Technology Education. 1 $-11$.

Sugiyono. (2008). Metode Penelitian Pendidikan. Bandung: Alfabeta.

Susilawati, \& Febrian. (2016). Analisis Kesalahan Siswa Kelas X MIA 3 SMA Negeri 1 Tanjungpinang Tahun Pelajaran 2015/2016 dalam Menyelesaikan Permasalahan Peluang Dengan Menggunakan Kategori Kesalahan Watson.

Wiens. (2007). An Investigation into Careless Errors Made by 7th Grade Mathematics Students. Lincoln: University of Nebraska

IJEME, Vol. 4, No. 1, March 2020, 31-42. 